\title{
'From the Face of My Memory': How American Women Journalists Covered the Spanish Civil War
}

\author{
Noël Valis ${ }^{1}$
}

Published online: 18 October 2017

(C) Springer Science+Business Media, LLC 2017

I begin with these words from St. Augustine's Confessions. "When I turn to memory, I ask it to bring forth what I want: and some things are produced immediately, some take longer as if they had to be brought out from some more secret place of storage; some pour out in a heap, and while we are actually wanting and looking for something quite different, they hurl themselves upon us in masses as though to say: 'May it not be we that you want?' I brush them from the face of my memory with the hand of my heart, until at last the thing I want is brought to light as from some hidden place" (195). In this extraordinary passage, Augustine seems to evoke Aristotle's notion that the soul is like a hand, for "as the hand is the instrument of all instruments, so is the intellect the form of forms" (145). These bodily analogies point to memory as a kind of place that is materialized through the senses, brushed with the hand of the heart. The "secret place of storage" recalls as well the classic mnemonic techniques of imagining memory palaces, rooms filled with pools of recollection. Augustine's face also veils deeper memories.

The face of memory can be seen as a form of prosopopeia, "the fiction of an apostrophe to an absent, deceased or voiceless entity" (de Man 926). Paul de Man conceived prosopopeia as "the trope of autobiography, by which one's name . . . is made as intelligible and memorable as a face" (926). But he also saw this face as irrevocably tied to figurative de-facement. We see faces like words: as parts of a whole ("Study Shows"). This partial vision is already a kind of defacement, in that we must first put together that which escapes

Noël Valis

noel.valis@yale.edu

1 Department of Spanish and Portuguese, Yale University, 82-90 Wall Street, New Haven, CT 06520, USA our understanding. The parts prevail as a whole, but the whole is subject to making these parts intelligible, an act of disembodiment, or disarticulation, that inevitably removes the whole-here, the face-from its immediate and full apprehension. $^{1}$

De-facement is, in this sense, a form of displacement. Perhaps the largest displacement of all, other than death, is war. War, in all its bodily offense, is paradoxically a kind of disembodiment because it displaces us from everything that we think of as "home," when we think of home as an embodied state of being. What is the face of memory like in the presence of war? What is the face of war? Salvador Dalí visualized it in 1940 as floating death in the shape of a disembodied head, a visage of fixed horror and misery, populated by other similar faces reproduced in the mouth and eyes, with even tinier faces inside, the jaws of serpents snapping at the image, a picture that only the vandalism of the human soul could have produced.

The faces of war multiply infinitely, as Dalí's painting suggests, but one conflict in particular comes to mind here: the Spanish Civil War (1936-1939), often seen as both the military and ideological testing ground and precursor of World War II. This war sparked the imagination and allegiance of many non-Spaniards, making it one of the most international of civil conflicts, pitting right against left, fascist against communist, conservative against liberal. There were many faces to the Spanish war, and many who came to find those faces, among them, a small group of American women journalists, all supporters of the Second Republic, whose work is mostly forgotten as they too have mostly receded from public view. Like the displacements of war itself, these women-Martha Gellhorn, Josephine Herbst, Frances Davis, and others - were

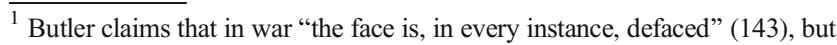
such de-facement is not limited to war or its consequences.
} 
also displaced, they were not at home in the world, but rather found, if somewhat uneasily, their place in the ruin of houses and dead bodies, the photographic image of Spain that Virginia Woolf wove obsessively into her essay, Three Guineas. This displacement of war and of women is representative of a much larger sense of the word in so far as displacement, beyond the obvious physical mass dislocations of peoples, constitutes a general structure of feeling characterizing the period. ${ }^{2}$

This notion of a structure of feeling is what Raymond Williams understood as the process of signaling change while experiencing things without yet entirely grasping their significance because the passage through that experience has not acquired a fixed, definitive shape. George Orwell, in Homage to Catalonia, said that "[w]hen you are taking part in events like these [here, the internecine struggle among Republican supporters in May 1937, Barcelona] you are, I suppose, in a small way, making history, and you ought by rights to feel like an historical character. But you never do, because at such times the physical details always outweigh everything else" (139). "If this was history it did not feel like it," he concluded (140). History is what happens after history has had its day. If news is the first draft of history, as the Washington Post's Phil Graham used to say, no doubt optimistically, then Orwell's written memory of those events in May is more like a second or third enriched version of the past (see Sommerville 81). Yet even he despaired of recording anything more than "some of the outward events." Because, he wrote, "I cannot record the feeling they have left me with" (230).

In the writings of the three women journalists I would like to examine here, displacement is the key metaphor and movement that structures their reporting and memories of the Spanish war. ${ }^{3}$ Uncertainty, confusion, and awkwardness symbolically marked that displacement, suggesting that the straitjacket of ideology and politics (here, leftwing), while always present, was not necessarily self-sufficient to explain the complex reality of their experiences in Spain because those experiences appeared either as out-of-synch with what they believed, or as apparently non-ideological. Overtaken by reality, writers like Martha Gellhorn, Josephine Herbst, and Frances Davis created a subtle counter-dance between the fugitive and the fixed, between displacement and embodiment by fusing the face of war with the face of their memory. This doubled face of war and memory is not unique to women journalists, though issues of gender certainly color their writings. Orwell began Homage to Catalonia with a fleeting but intense encounter with an Italian militiaman. "Something in his face deeply moved me," he wrote. He went on to say, "[i]t was

\footnotetext{
${ }^{2}$ I am indebted here to Marshall Berman's idea of the experience of modernity as "a struggle to make ourselves at home in a constantly changing world" (6).

${ }^{3}$ For more on the women journalists who covered the Spanish Civil War, see Sorel; Hartmann; Preston; Hochschild; Vaill; Keene; Usandizaga; and McLoughlin.: My thanks to J.R. Sabín Lestayo for his bibliographical help.
}

as though his spirit and mine had momentarily succeeded in bridging the gulf of language and tradition and meeting in utter intimacy. I hoped he liked me as well as I liked him. But I also knew that to retain my first impression of him I must not see him again" (3-4). In this way Orwell created an ideal memory, the militiaman typifying for him "the special atmosphere of that time. He is bound up with all my memories of that period of the war" (4).

Later, he referred to "the faces of militiamen" that filled him with unarticulated feelings. These same faces were an obsession for the poet Antonio Machado during the war, who saw in them not only solidarity and comradeship but a kind of transcendent nobility before death, remarking on "the noble dignity of their faces." "Their faces," he wrote, "possess the grave brow and the concentrated expression absorbed in the invisible, of those who would lay down their lives for what they believed in" (Machado 289; see also Sánchez Barbudo 17-22). Such faces were a revelation for Octavio Paz: "[I]n those faces-obtuse and obstinate, gross and brutal . . . - there was something like a desperate hopefulness, something very concrete and at the same time universal. Since then I have never seen the same expression on any face" (25). Newspaperman Jay Allen wrote of "the bewildered faces in the dawn, the dead faces in the mud" he had seen, of the photographs where here too, he said, "I saw the face I knew, the true face of Spain" ([1]), while Hemingway, in the narration to the film, The Spanish Earth, spoke of "soldiers with the true faces of men going into action. It is a little different from any other face you will see" (see Coleman; and Wood). ${ }^{4}$ Infused with political belief systems, these images idealize the war and the men who fought and died in it, but also give us glimpses into something obscurely intuited in a kind of practical consciousness, of "what is actually being lived," as Williams expressed it (130-31). This sense is especially felt in Orwell, Machado, and Paz.

Since the Crimean War, war correspondents have tended to divide into two different groups, though with considerable overlap. As Phillip Knightley observed, either they were battlefield reporters or they were human interest journalists, focusing on the impact war had on individuals (8). By the 1930s, a "New Reportage" had emerged in the U.S., a product in part of the Depression and New Deal programs like FERA

\footnotetext{
${ }^{4}$ Jasper Wood, an eighteen-year-old high school student who idolized Hemingway, put together a written version of his narration in the film, remarking: "In [the film], we see faces, faces in battle and going to battle, faces in charges and retreats, faces of young and old, faces fired with loyalty and honor, tired faces, and faces white as chalk which will never see or grin or smile again, and then you see what is left of many faces, mostly parts of faces and sometimes no face at all. Never before has such dramatic use of the face been incorporated into a picture" (Wood 13-14; also Marsh; and Davison, who reprints Wood's introduction). The photographs to which Jay Allen refers are those of Robert Capa and Gerda Taro reproduced in Death in the Making (1938); see also Valis 125-27, for more on the significance of faces during the Spanish war.
} 
(Federal Emergency Relief Administration) that sponsored field reporting, but with a tradition going back to the muckrakers and Jack Reed's Ten Days That Shook the World (1919). Politicized, self-reflexive, and emphasizing lived experience, such reporting was motivated by the urgent need to "find out," to "know" (see McLoughlin 25-30). The New Masses editor, Joseph North, wrote: "To the writer of reportage, the fact he is describing is no corpse, it is alive, it has a place on earth" (McLoughlin 25). This kind of writing, I would suggest, lends itself to an analysis of a period's structures of feeling.

Martha Gellhorn, who had worked as a field investigator for FERA, came out of that tradition. Best remembered of all the women journalists of this era and a pioneer war journalist in her own right, Gellhorn (1908-1998) was from a liberal, reform-minded family in St. Louis, Missouri. ${ }^{5}$ She had already written her first novel and a book of short stories by the time she met Ernest Hemingway and eventually became his third wife. In Spain, their affair quickly was outed, putting Gellhorn, who already felt she was tagging along, in an awkward position (Face 12; "Memory" 3). Additionally, she arrived in Madrid with only a vague accreditation from the popular magazine Collier's. More generally, like most other reporters, she was drawn to Spain by politics, but aware that reporters were sometimes viewed as war tourists, an accusation that was hurled against Hemingway. ${ }^{6}$ As Ilsa Kulcsar, the wife of writer Arturo Barea, put it, "We are here for the story, but they [the Spaniards] are here for their lives" (Vaill 89; orig. emphasis).

Gellhorn's war reportage was published in Collier's, The New Yorker, and Harper's Bazaar, some of it later collected in her book, The Face of War (1959), which showcased her experiences in Spain, Finland, China, and Europe during World War II. ${ }^{7}$ A pacifist, Gellhorn turned fierce anti-fascist after a few months in Nazi Germany. Looking back, she saw herself as hopelessly idealistic, believing that what she wrote could change the course of events. By the Second World War, she had few illusions. "I was a special type of war profiteer," she wrote. "I was physically lucky, and was paid to spend my time with magnificent people" (Face 3). Nonetheless, she insisted on the truth value of these pieces: "they tell what I saw. Perhaps they will remind others, as they remind me, of the face of war." For Gellhorn, still the idealist despite

\footnotetext{
${ }^{5}$ For more on Gellhorn, see: Rollyson; Moorehead; Dell'Orto; McLoughlin; Hartmann; and Vaill. Dell'Orto places her work within the category of literary journalism, a form of writing that also applies, in my view, to Herbst and Davis (303).

${ }^{6}$ Gellhorn wrote of herself: "I had no idea you could be what I became, an unscathed tourist of wars" (Face 12). See Milton Wolff, the Lincoln Battalion's last commander, for his scathing characterization of Hemingway (Nelson 13).

${ }^{7}$ Expanded, The Face of War also had editions in 1967, 1986, and 1993. I cite from the original 1959 publication.
}

herself, "memory and imagination ... are the great deterrents" (Face 8).

Gellhorn chose to write about ordinary people during the war, soldiers and civilians. As she observed, "[w] hat was new and prophetic about the war in Spain was the life of the civilians, who stayed at home and had war brought to them" (Face 13). ${ }^{8}$ The walls of the Hotel Florida where she and most reporters stayed in Madrid shook daily with the kind of massive civilian bombing no one had ever seen on this scale before. The front was only fifteen blocks away from the hotel, in University City. You could walk to the battlefield. More significantly, the "whole city was a battlefield" (Face 11). The war was everywhere, a bit like God. You couldn't escape it.

By extension, if the war was everywhere, it was also nowhere, in the sense that there was no clearly demarcated space that spelled out war. ${ }^{9}$ Gellhorn captured this cruel paradox beautifully. In "Only the Shells Whine," published in Collier's (17 July 1937), but not included in the first edition of The Face of War, she explained what the impact of a falling shell was like: "You would be walking down a street, hearing only the city noises of streetcars and automobiles and people calling to one another, and suddenly, crushing it all out, would be that huge stony deep booming of a falling shell, at the corner. There was no place to run, because how did you know that the next shell would not be behind you, or ahead, or to the left or right? And going indoors was fairly silly too, considering what shells can do to a house" (13). ${ }^{10}$ Then there is a lull:

An old woman, with a shawl over her shoulders, holding a terrified thin little boy by the hand, runs out into the square. You know what she is thinking: she is thinking she must get the child home, you are always safer in your own place, with the things you know. Somehow you do not believe you can get killed when you are sitting in your own parlor, you never think that. She is in the middle of the square when the next one comes.

A small piece of twisted steel, hot and very sharp, sprays off from the shell: it takes the little boy in the throat. The old woman stands there, holding the hand of the dead child, looking at him stupidly, not saying anything, and men run out toward her to carry the child. At their left, at

\footnotetext{
${ }^{8}$ Though a few years later she also wrote that "[a]nybody who has seen part of any war can imagine every war" (xiii) (Introduction, 1967 [1986 ed., The Face of War]). True enough, but the Spanish Civil War created a passionate sense of political and ideological identification with Spain rarely seen in other civil conflicts.

${ }^{9}$ See Santiáñez's discussion of location in his incisive Goya/Clausewitz (1324).

10 "Only the Shells Whine" appears as "High Explosive for Everyone" in the 1986 edition of The Face of War; I cite from Collier's. Practically every reporter in Madrid had stories of shelling, as Gellhorn wryly reminds us in "A Sense of Direction": "There had been nothing to write about for weeks since no one anywhere was interested in another shelling of Madrid" (139). See, for example, Josephine Herbst, Starched Blue Sky 152-53; and her unpublished diary $4,8,13,39$.
} 
the side of the square, is a huge brilliant sign which says: Get out of Madrid (64).

The shelling is everywhere, so that the very notion of home comes under attack. The old woman never makes it home, and even if she had, it isn't safe, that's Gellhorn's point. Home just got skewered with the same small piece of twisted steel. If the point wasn't clear enough, the get out of town sign is. Home is these two displaced persons, caught in the middle of the square, an urban no man's land. By the same token, war isn't any easier to find, because it isn't a battlefield, but right behind you, or maybe by your side or over your head. What Gellhorn asks is: how do we locate where war is? This is a question we ask ourselves a lot nowadays. Her own moveable perspective in this passage, shifting from third to second person and back, between distance and intimacy, complicates that location.

To remember, first you have to make a place for what it is you wish to remember. Years later, in one of the last pieces she wrote, she said that memory is incoherent without a temporal structure. She thought her own memory evoked disconnected images because she had "no grasp of time" ("Memory" 3), but memory is also profoundly spatial. In these essays on the Spanish war, Gellhorn went from place to place, creating a kind of moving collage of memory (McLoughlin 43). She visited the front and went to hospitals, but above all, she wandered the streets and found houses. Some were like doll houses, with gaping fronts; some had dangling floors and the furniture blown away. These were not homes "because there was nothing left to live in." They were more "like scenery in a war movie: it seemed impossible that houses could really be like that" ("Only the Shells" 64).

In another piece, "The Besieged City," she discovered "there is also a first-aid service for wounded houses," so she followed the staff of architects, engineers, bricklayers, and electricians on their rounds (16). ${ }^{11}$ The last house they visited has nothing left at all, only an old woman who says: "Look at that, look at that, do you see, that is my home, that's where I live, there, what you see there." "I do not understand," she said. "You see, it is my home" (19). Gellhorn lets the words stand, as though words were the missing walls. By contrast, staff headquarters was in a bombed apartment house. "It was," she wrote, "a homelike spot: there were three women, the wives of officers, shrill as birds," with a baby asleep on the sofa. Here too was war and "it was right in the city" (20). The distinctions between front and home have become blurred, making a new composite of what used to be the home-front. Meanwhile, in the trenches, as the war of propaganda goes on nightly with competing loudspeakers, she remarks how "very much at home" the soldiers seem. It's like a summer concert (22).

\footnotetext{
${ }^{11}$ First published as "City at War" in Collier's (2 Apr. 1938). I cite from The Face of War.
}

Broken houses are like broken bodies, a displaced simile that Gellhorn creates as her own narrative works through displacement, moving between ruined houses and ruined bodies. In "Only the Shells Whine," she visited a janitor's family in their tiny basement apartment. The eight-story building itself was a shell, with only the walls standing. From there she walked to the Palace Hotel, now a military hospital. "One of [the men]," she wrote, "I tried not to look at. I was afraid that I couldn't look at him without showing it on my face." But she did look: "He was blond and young, with a round face. There was nothing left except the eyes. He had been shot down in his plane and burned, but he had been wearing goggles and that saved his sight. His face and hands were a hard brown thick scab, and his hands were enormous; there were no lips, only the scab" (65). This "charred face" appears as the embodied reality of Dalí's later "Face of War."12

In "The Third Winter," dated November 1938 (from The Face of War), Gellhorn was in Barcelona. She made visits to a fellow named Hernández's home, a shop, a hospital, and the headquarters of the pro-Republican International Brigades, but she kept coming back to the Hernández family, so that the sections on the family are interspersed, broken into dislodged narrative fragments. A carpenter, he collected "the fragments from destroyed houses, he said, not to work with, but for firewood, but now that is all saved for the hospitals" (27). Later, she described his daughter-in-law's baby: "The face seemed shrunken and faded, and bluish eyelids rested lightly shut on the eyes. The child was too weak to cry" (32). This section of the essay leads to the next, focused on the unheated children's pavilion of a large hospital. The nurses fretted over the inadequate food rations. "The children looked like toys," Gellhorn observed, "until you came closer-tiny white figures propped up with pillows, swathed in bandages, the little pale faces showing, the great black eyes staring at you" (33). One little boy, wounded like all the rest, wailed in grief, homesick for his mother who eventually arrived, looking "gaunt and a little mad" and bringing devastating news: a bomb had completely destroyed their home. "She told the round-eyed child the story of woe and he listened with interest and sympathy and wasn't homesick any more" and she gave him a pot of cold rice. "He seemed happy then and at home," she wrote (35). (This phrase, "at home," appears, in different contexts, several times in Gellhorn's Spanish Civil War writings.) Here, home is emotionally restored because home is the mother herself, just as her story rebuilds home in the child's imagination.

After this section, Gellhorn returned to the Hernández family, where she knows the daughter-in-law's baby "probably

\footnotetext{
12 The theme of wounded soldiers also appears in her "Men Without Medals" (Collier's, 15 Jan. 1938): "in time of war, the faces above the sheets are all young faces" (49). See also "Madrid to Morata." A hospital visit in 1945 evoked the suffering of Republican exiles in French concentration camps ("The Undefeated," orig. Published in Collier's, 3 Mar. 1945).
} 
will not live until summer." She immediately swerved away from the thought: "Let's talk about something else, now, just for a change," which is directed not to the Spaniards but to herself. "We all stay home," old Hernández says to her (36). Gellhorn's characteristic use of understatement at once constructs and deconstructs home, marking the sites of vulnerability. ${ }^{13}$ Nothing has solidity, despite Mrs. Hernández's brave words at the end of the piece, "We are all right, señora," to which she adds: "We are Spaniards and we have faith in our Republic." By November 1938 everyone knew the war was lost. But Mrs. Hernández has "the last word in her home about her family," as Gellhorn put it (41). This persistence of place in the midst of ruin suggests the same collapsing order as in Dalís "The Persistence of Memory" (1931), where clock time softens and melts but still occupies spaces. Clock time is a figure of displacement for other, deeper forms of time, for things lost to time and in time, in the sere landscape of memory. Houses are a figure of displacement for other, deeper places of the heart called home, the façade cracked, with glimpses of an underlying, terrible sense of loss that cannot be fully stated. The face of memory is also de-facement in time of war, brushing aside unwanted or unbearable memories. ${ }^{14}$ The structure of feeling that emerges here-profound displacement in a world not at home-is grasped as it teeters between unspoken experience and provisional meaning.

As with all such experiences of lived intensity, there comes a moment when, Gellhorn wrote, "[w]e were sick of the war" ("Zoo" 47). "Zoo in Madrid," first published in Harper's Bazaar (July 1937), was reprinted in The Heart of Another (1941), a collection of stories. A bunch of American journalists decide to take the day off and manage to get inside the off-limits Retiro Park. The guards also show them the zoo, where they admire the hippopotamus, the baby llama, and the "superb great yak," even as the narrator asks, "Is there really a war going on?" The zoo appears as a distraction, an odd gesture toward the normal, until the journalists leave: "Walking slowly, we began to talk about the war. We did not think any one would believe us when we got home, or understand, or even care. They would not know, we decided, how important this war was because it was like nothing else before it. We said to each other the things we already knew by heart: that we had never in one place seen people so different, so real, and so disinterested. Then we began to talk about how incredible it was to have everything mixed up together, the zoo and the gun positions behind the statue [of Alfonso XII], and the café that grew up in one half of a shelled building" (95). Gellhorn uses two interlocking techniques, display and isolation: first, she puts on display the apparent focus of her piece - the zoo - only to make clear toward the end that the real object of interest is the war. "We were sick of the war" is the

\footnotetext{
${ }_{13}$ Usandizaga calls Gellhorn's narrative technique "minimalist" (174).

14 See Levinas, who remarks on "the face as the extreme precariousness of the other" (167).
}

opening sentence, meant to make you swerve away from the subject at hand. In truth, the visit to the zoo provides the narrator with the mechanism to isolate the war as the elephant in the room. Because all the while no one can really forget the war. It's not just the animals that are on display in this piece; so are the journalists and the madrileños. Looking at the things in the park and the animals in the zoo simply reinforces the abnormality of war: how everything is out of order and out of place, but also on display. Guns adorn the monument to Alfonso XII and a café operates amid bombed chaos. A trail of blood glistens near Chicote's bar, where the journalists are headed. And is there anything less normal than going to the zoo in the middle of a war? Alternatively, the war can be seen as normalized, thus putting into question what normalcy means. ${ }^{15}$

The zoo is another way of saying that Gellhorn isn't certain how to talk about this war, how to communicate the experience of being there. ${ }^{16}$ The war is a confused mess, as heterogeneous as the zoo itself, with animals, sculptures, guns and a café all thrown together, like the ruined other half of the building where the café is located, with "chairs hanging on a chandelier, an iron stove that was hurled down through the floor ... cracked mirrors and the usual inevitable masses of waste paper" (95). Elsewhere, she asks, "How is it going to be possible ever to explain what this is really like?" ("The Besieged City" 25). Rhetorical questions find an echo in the repetition of phrases. She repeats to herself, "what was it like," in imagining the theater of war, and in the same piece, she ends with the reiterated "you can think of it," because, she says, the men in this war "knew why they came, and what they thought about living and dying, both. But it is nothing you can ask about or talk about. It belongs to them" ("Men Without Medals" 49). In "Only the Shells Whine," she concludes with what she knows, as here: "You know that in November there were black Junker planes flying over and dropping bombs, that all winter long there was no fuel and the days were cold and the nights were colder, you know that food is scarce, and that all these people have sons and husbands and sweethearts at the front somewhere" (65). But this knowing occludes what she cannot talk about, the intimate experience of war that as an observer she cannot know and the broader experience of obscurely intuited momentous change. Her reflections on memory at the end of her life make transparent what was implicit in her earlier war writing: "Unexpectedly, [memory] flings up pictures, disconnected with no before or after. It makes me feel a fool. What is the use in having lived so long, travelled so widely, listened and looked so hard, if at the end you don't know what you know?"

\footnotetext{
${ }^{15}$ McLoughlin observes that the "normality trope" in Gellhorn's writings also works as "a device with which, she firstly suggests war's closeness through familiar comparisons [between things Spanish and things American] and, secondly, reveals Americans' involvement in the conflict" (45). This trope is found as well in the writings of Herbst and Davis.

${ }^{16}$ The ultimate unsayability of wartime experience is a constant in such writings. See Santiáñez's "Showing What Cannot Be Said."
} 
Gellhorn was not alone in her uncertainty. Also a midwesterner, Josephine Herbst (1892-1969) was born in Sioux City, Iowa. ${ }^{17}$ By the time she went to Spain in the spring of 1937 , she was already a well-known novelist and story writer. (By the time of her death she was mostly forgotten.) Her politics were to the left, with communist sympathies. As in the case of Gellhorn, her press credentials were of the haziest, without a clear newspaper assignment. (This was also true of Frances Davis.) Unlike Gellhorn, she wrote very little about the war at the time: "Apart from a few news accounts, a few descriptive articles, I have never written anything about Spain. It had got locked up inside of me" (Starched Blue Sky 131). ${ }^{18}$ Her remarkable memoir on the war first appeared in the short-lived little magazine cofounded by Saul Bellow, The Noble Savage, in 1960, and was reprinted posthumously as The Starched Blue Sky of Spain and Other Memoirs in 1991 (see Burns).

Why was she unable to write about Spain until then? At first she says it was impossible because everyone "wanted the authoritative answer" on the war, nothing contradictory or gray (Starched Blue Sky 131). ${ }^{19}$ Of course the anti-Stalinist Marxist Andreu Nin was a fascist fifth columnist working for Franco. But Herbst wasn't sure of that (and history has proven her to be right). Yet there was more to her writer's block than political correctness, though ideological self-censorship in defense of the Second Republic cannot be ruled out (see SuárezGalbán 241-42). She also said, "it may have seemed to me that what I had brought back was too appallingly diffuse" (131). The phrasing is odd, cautious on the one hand ("it may have seemed to me") and almost oxymoronic on the other ("appallingly diffuse"). Why "appallingly"? Her unpublished diary of the period offers clues. She had collected bits and pieces and none of it hung together. Tellingly, the diary seems disjointed, her biographer calling it incoherent and incorporeal (Langer 211). I gleaned two things from her journal. She wasn't able to grasp the big picture and she wavered at times between self-absorption and abstract fervor, between the personal and the political, unsure how the two fit together. ${ }^{20}$

\footnotetext{
${ }^{17}$ For more on Herbst, see: Langer; Roberts; Johnson; Hubler; De Bueriis; Sorel 35-41; Hartmann; and Usandizaga 163-69.

18 Among the Josephine Herbst Papers at the Beinecke Library, Yale University, are typescripts, one of which appears to have been prepared for a pro-Republican radio broadcast (see Langer 216); another on the shelling in Madrid; and an apparently early version of one section of Starched Blue Sky, the evening she spent in a village with German members of the International Brigades.

${ }^{19}$ Historians and others have mostly mined the material on the José Robles case in The Starched Blue Sky of Spain (see Preston, Vaill, Koch, and Martínez de Pisón). Robles, a Republican supporter, Spanish professor at Johns Hopkins University, and close friend of John Dos Passos, mysteriously disappeared during the war, presumed to have been murdered by the Soviets. My point here is that Herbst's memoir is also of great interest for other reasons as well.

${ }^{20}$ De Bueriis notes that "the intersection of personal and political themes" is of particular interest in Herbst's work (283), while Hubler argues her writing is "an attempt to demystify the structuring connections between the private and the public realms" (75).
}

It isn't surprising she couldn't yet see the larger vision, though her writerly eye was good at spotting revealing detail. Like nearly all the foreign war correspondents, Herbst knew very little about Spain. She wanted to tell the truth about the war, but, I suspect, wasn't sure where to find it. In her notes, she made this observation: "Write about (the truth - the terrible necessity of the truth) elusive but there, oh justice-blood and thunder stories not true" (30). Later, she jotted down: "say why I am here, really, truly. To tell news, propaganda for the cause. Viper's nest and I don't know it" (59). From this, one surmises that Herbst was beginning to realize how complicated the situation in Spain was, less black and white than the usual accounts, and how challenging it might be to square justice and truth with propaganda.This alone may have produced some of the diffuseness of which she complained in the published memoir. It did not diminish her enthusiasm for the cause, but did make it more difficult to write about.

On a personal note, Herbst was not at ease with herself. A rocky marriage was coming to an end, and she was drifting. She recorded notes on what happiness is in the journal, clearly not having found it (34). ${ }^{21}$ Her insecurities abound. Amidst the loud and terrifying shelling in Madrid, as "shells seem to be tearing right into the room" where people are congregated, she says to herself, "No one notices me" (4). At another moment, she observed that a colleague is "anxious about Hemingway and Virginia [Cowles, another correspondent]. No one anxious about me-would probably rot in street for days. Go to room and try to rest. Start crying for no reason. Want to be home" (130). Obsessed with the relationship between Hemingway and Martha Gellhorn, she lashed out at the glamorous Martha, calling her a whore who "gets pretty much around on what she's got. Don't mean in the head. The pants. Plays all. Take all. Never speaks of anyone not a name. Glib stupid tongue" (13). This material never made it into the memoir. Instead, she associated the apparently super confident Gellhorn with her own uncertainty and anxiety: "Other people came out of the hotel and set off briskly, but where did they go? Martha Gellhorn sailed in and out in beautiful Saks Fifth Avenue pants, with a green chiffon scarf wound around her head. Everyone knew where he was going, what he was doing, except me" (Starched Blue Sky 138). Gellhorn of course had no more idea where she was going than Herbst.

And she was no more at home in the world than Herbst. The Spanish Civil War stayed with both of these women (and with Frances Davis) for the rest of their lives. Why did Herbst

\footnotetext{
${ }^{21}$ These notes on happiness are transformed into something far richer in The Starched Blue Sky, as a soldier tells Herbst that people want happiness and "something to believe in." "But the word 'happiness' confused him, even pained him" (173). Herbst had married the writer John Herrmann in 1926.
} 
go to Spain? Even she couldn't explain it: "I didn't even want to go to Spain. I had to. Because" (132). She went on to say:

Don't expect an analysis of events. I couldn't do it then, I can't now. I have my opinions, but what I can only call my convictions go to deeper levels, where opinions hardly count . . . I can hardly think back upon Spain now without a shiver of awe; it is like remembering how it was to be in an earthquake where the ground splits to caverns, mountains rise in what was a plain. The survivor finds himself straddling a widening crack; he leaps nimbly to some beyond, where he can stand ruminating upon his fate (133).

Memory in this passage is more than a place, it is a geological cataclysm, a shattering of everything that went before, so that the landscape will never be the same again. She will never be the same again. What precisely is being shattered is not clear. But in this dramatic scenario Herbst has presented us with something less than history and something more than experience. The rupture creates the depths and heights of some obscurely grasped change that you understand has happened on a scale larger than the individual but that is intimately connected to the deepest levels of the individual. Herbst has given us a structure of feeling in this memoir that affects both inside and outside. She says, "If I seem to be going into subterranean regions, it is because these regions, as related to myself, are what I know. I don't know anything really about Spain except what came through me and my skin. I believe that my own deeper feelings about myself and the way those feelings attached themselves to the fact of Spain applied to many more than myself. In a certain sense I hoped to find in Spain an antidote to the poison I found in Germany [in 1935]" (134-35)..$^{22}$

The earthquake that is Spain acts as an enormous dislocation in Herbst's memoir. On the other hand, the "fact of Spain" seemed to situate her, attaching her to something even if that something is not clearly articulated, reflecting "the confusions in [her] own mind" in the turbulent thirties (135). For Herbst, as for Gellhorn and Davis, ideology (left-wing in this case) was one thing, social and political upheaval another. It is easy to dismiss her comments as fuzzy thinking, but that would be missing the point: upheaval of this magnitude overwhelms. Have we ever come to grips with the historical-social chaos and tumult of the twentieth century? Herbst's immediate reaction to Spain was, however, more down to earth: "My entry into the Hotel Florida in the heart of Madrid was surprisingly cozy." Hemingway gives her a big hug, recalling how she let a kingfish slip off her line in Key West. "I was grateful for the

\footnotetext{
$\overline{22}$ Roberts wonders why her memoir does not discuss such concrete things as land reform, as Herbst does in a piece for The Nation called "Spanish Village," but this and other passages suggest other aims in mind, rooted in retrospection (see Roberts 211-12; also Herbst, "No Sanctuary").
}

reference," she wrote, "which seemed to bring the world together and hold the disparate parts in conjunction. Hemingway was at home, if I wasn't, and that was something" (136). The notion of home/not-home, which we have already seen in Gellhorn, is reinforced with another story she tells the soldiers: "At the Florida I was always having this dream of coming home from school and smelling my mother's wonderful homemade bread." She hears thunder, shuts the windows, and wakes up. "There was no bread and no thunder. Only the noise of the early bombardment" (148). A real memory becomes a phantom one; home, a dream.

The unreality of home, relocated in dream time, is akin to the "misty sort of unreality" she associated with the Hotel Florida. "I never seemed to be there, even when I was actually there," she wrote. "Something inside seemed to be suspended outside, waiting. .. There was a disembodiment about my own entity, which didn't even disturb me. I soon got used to it. There was a kind of distinct core inside me, around which the disembodied elements might cluster as around a magnet" (137). Herbst's homeless psyche is like the Hotel Florida: filled with disembodied elements, like the people constantly milling about the hotel, all around her. Her feeling of suspension recalls the "colloidal environment" of Salvador Dalís mind, the image of one substance suspended and dispersed throughout another, like "the arborescent blossoming of agates" in which "the spectral apparition of the plant" is found in the mineral (Dalí 2-3, 4). Or his "Face of War," in which miniature forms of death are hangared within, on an indefinite layover. On a practical plane, Herbst felt awkward, "suspended" because she had no real press assignment (Starched Blue Sky 139). As with Gellhorn (and Davis), her situation as a woman reporter was anomalous.

So she does what Gellhorn and other correspondents did: she went out on the streets, visited the trenches, hitched a ride with the first available car to nearby villages. She wrote, "I did a lot of walking around, looking hard at faces" (139), as though faces could tell you things. And maybe they did for Herbst, as this ideologically infused comment suggests: "The place [Madrid] had been stripped of senseless commodities, and what had been left was the aliveness of speaking faces" (140). ${ }^{23}$ One night, she ran into German volunteers, part of the International Brigades, chowing down in a village. "The faces had a curious uniformity: I can only describe it by saying that they looked confident and joyful. One has to remember that these men had been summoned, as it were, from the shadow of a cellar" (165). In her journal notes, she alludes to this same scene, jotting down: "live live faces. Where again such faces" (44). And this: "The sunburned alive faces . . . Expressions in faces. Finest faces in the world. These fellows know what it

\footnotetext{
${ }^{23}$ In a typescript, she wrote: "I keep seeing their living faces and the living face of all Spain" (Josephine Herbst Papers, Beinecke Library, Yale University).
} 
means" (46). ${ }^{24}$ Or the fifteen-year-old Spanish boy, whose "face as he sang with clenched fist [was] very determined and beautiful." "These are the NOT WANTED MEN" (46; orig. emphasis), the men who couldn't go back to their own country after the war was over, for obvious political reasons. Her notes were distilled by time and memory into a moment that for Herbst held "a celestial quality," what she called "the fact of the now." "[T] he saving grace was to use the now as if it were literally the forever" (Starched Blue Sky 165; orig. emphasis), inevitably recalling the driving "now and forever now" of Hemingway's For Whom the Bell Tolls. These faces are like "the fact of Spain" for her, possessing the unquestioned clarity of political conviction. They can be located, if only in the now of experience, and recalled as the face of memory.

By contrast, near the end of the memoir, another face appears. An American soldier from the Jarama front tells Herbst about the night he helped his wife deliver their baby because no doctors were available. That story and the night in the trenches "all got mixed up together." As they walked in the dark, Herbst stumbled and he caught hold of her. "I could not see his face," she wrote, "only feel how he felt and that he was sorting things out from a jumbled mass of experiences if only to make some order to help him to live" (174). Here, not seeing his face becomes part of the dark and confusion of heightened experience. Death in the trenches matched with new life. The unseen face is as vividly recalled as "the aliveness of speaking faces," for this too is a speaking face, a form of disembodied prosopopeia to remind Herbst that she is walking alongside a premonition of death. "The dead," she says, "were present by their absence. The dead often seemed as real to me as the man who might be talking of his friend" (146). Or of his wife.

These faces of war are the face of her memory, tangled like the soldier's experience or Martha Gellhorn's. "Please to remember them," she wrote (146). But what exactly was Herbst asking us or herself to remember? Her view is partial, as she herself recognized in describing, for example, the terrain near an embattled village: "I never saw this hilltop as a whole scene, but saw only its parts as they met the hurrying eye, because it took all of one's concentrated energy to get across this emptied space" (143). And when a townsman claimed "she understands everything!", she wrote, "But I was far from understanding everything. About the most important questions, at that moment, I felt sickeningly at sea" (178).

If Herbst was at sea, Frances Davis (1908-1982) found herself in an equally intolerable position, having ended up by chance in the Franco-led Nationalist zone. As she put it, "I had been deposited [in the country of the Generals] by the meanderings of a mountain road; by having come to Spain on

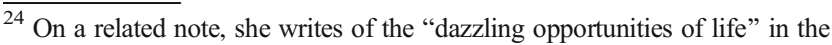
midst of war ("Three Books" 20).
}

a train to Hendaye instead of Perpignan" (Fearful Innocence 139). Of these three women, Davis has truly fallen into a memory hole. The product of a radical utopian community, The Farm, in West Newbury, Massachusetts, with parents committed to trade unionism and social work, by the age of thirteen she was in her element working as a printer's devil at the Medford Mercury. ${ }^{25}$ Breaking into the business of foreign correspondent, however, proved much more difficult. Davis's story makes explicit how out of place these women war journalists were. The account of her experiences in Spain first appeared in 1940, in My Shadow in the Sun and, in 1981, in chapters 10 and 11 of her memoir, A Fearful Innocence. This later publication is a distillation of the earlier book, with some rewriting and rearranging of material. Notably, My Shadow in the Sun is almost entirely narrated in the present tense, while the passage of time has converted a narrative present into past tense in A Fearful Innocence.

With few credentials, she was doing what was known as mail copy, selling stories to country papers unable to pay for cables. A veteran newspaperman told her, "There's very little chance for a woman in the foreign field. If you can be discouraged, I want to discourage you" (Fearful Innocence 119). But J.W. Terry did help her after all, with good practical advice for improving her writing skills and selling those skills. Davis took off for Paris in 1936 with no idea what she was going to do. Her 1940 account begins there, trying to find the local phone number of the Chicago Daily News. The Paris telephone book is unfamiliar to her. "I am clumsy-witted and forget what letter comes first and have to spell the alphabet out" (My Shadow 9). This awkwardness was soon joined to feeling aimless, while she waited around in Hendaye across the border from Spain (38). Like Gellhorn and Herbst, she knew she was tagging along with the men reporters on assignment. "Somewhere within me," she wrote, "there is the cloud of discomfort at being where I am not wanted" (69). Bertrand de Jouvenel, future philosopher and political economist, laughed when she ordered dinner for the group, and said: “'Wonderful! Isn't she wonderful?' He is amused and I am feminine and he is French" (72). ${ }^{26}$ The irony is unmistakeable. Davis saw herself on the outside looking in, as the men fraternized and shared information with each other $(M y$ Shadow 70; Fearful Innocence 134). But she won them over, when she volunteered to smuggle their stories into France, by hiding them in her girdle, thus avoiding Nationalist censorship. This also landed her an assignment with the pro-Franco Daily Mail.

\footnotetext{
${ }^{25}$ See Keene $69-72$; Sorel 28-32; Usandizaga 159-63; Hartmann; and Schlesinger ix-xii, for more on her life. Prolonged illness forced Davis, who later married I. Bernard Cohen, the renowned historian of science, to give up her journalistic ambitions. Roughly the last third of My Shadow in the Sun (chapters 9-16) focuses on the near fatal infection, possibly septicemia, that laid her low while in Spain and afterward.

${ }^{26}$ I do not know if Martha Gellhorn and Frances Davis crossed paths, but de Jouvenel knew them both. He had an affair with Gellhorn in the early 1930s.
} 
Daring, tenacious and impetuous, Davis threw herself into things without always knowing why. As she observed, "[i]n this preoccupation with how to get into Spain, I had not asked myself who was at war. Few of us knew much about recent Spanish history" (Fearful Innocence 138). This remark suggests she was apolitical, as at least one critic believes (Usandizaga 161); yet neither her background nor her account support that view. As a courier, she found herself shuttling back and forth between Burgos, the Nationalist headquarters, and France, but this physical movement occluded an underlying tension that pingponged between professional fulfillment and personal anxiety, leaving her in an untenable position as a secret Republican supporter in enemy territory. The unbearableness of her situation is not immediately clear either to Davis or to her readers, though a vaguely articulated unease, a feeling of being exposed, manifests itself fairly early.

At one point, she wrote in her memoir, "There is a feeling of precarious balance" (Fearful Innocence 137). The statement comes shortly after witnessing from a hotel balcony nighttime firing in a cornfield. "This Spanish corn was inhabited. .. but by men who lay on the chill wet earth alone, hidden to their enemy. .. The man out there, secret in the cornfield, was vulnerable. He and I were one. I was no longer an observer at somebody else's war, on somebody else's planet. I, too, was flesh and bone. I, too, could be shattered by a bullet" (136). What appears to be the same episode was described very differently in 1940 :

The tall corn bends to the river breeze. Between the rows of the waving corn the figures of men move. I can see the expression upon their faces. I can see the tenseness with which they concentrate upon each movement. And when one opens his mouth it is his face that I see screaming because I cannot hear the sound that issues from his mouth. A hand waves above the corn tops and the body falls down out of the line of my vision. A second man spins and goes down with his arms out to embrace the corn (My Shadow 118).

The scene is set in daylight, and Davis's tone is as distanced in space as it is in perspective. By 1981, the passage of time has turned the original moment into something oddly intimate. What is not altogether clear, however, is the political identity of the man. Was he Republican or Nationalist? Does it matter? I think it does, to the degree Davis's narration suggests the slippery place of her own position in this scene (and in Spain), attached as it is to a gesture of identification characterized as secret and vulnerable. ${ }^{27}$ Vulnerable in her own skin, but opaque otherwise.

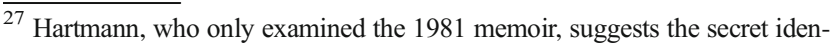
tification was the shared Republican cause (34).
}

If war can be difficult to locate because it is an ever-present, protean displacement, as Gellhorn shows, here, the writer herself suffers her own kind of dislocation, which is beautifully expressed in the image of a moving car. She writes,

I live upon the roads of Spain . . . I live in this car, shuttling back and forth, Burgos to France and France to Burgos. The car is my house, my bed, my skin. I eat in my moving car; a roll, a slab of meat, a bottle of wine. The roll and the meat in one hand, the bottle in the other, my sight dead and unperceiving upon the familiar road. I sleep in my moving car, my head upon the back of the car seat; sleeping at night, sleeping in the daytime, sleeping whenever there is no longer any purpose to waking. I work in my moving car, my typewriter upon my lap, pounding at the keys without disturbance from the swaying of the car as it flies over the lifting and falling and turning of the road (My Shadow 124-25).

The car as home is really no home at all, her life as courier a continual physical displacement amid the huge upheaval that is the civil war. The use of the present tense here and throughout the book underlines the same nowness seen in Herbst's memory of the war, as though actualizing memory itself while oddly postponing the past in a series of displacements, all while transmitting her storyline.

Displacement is more than physical in Davis's work. It is also political. "There are the never-ending tensions of the guards upon the road," she observed. "It is true, they are now my friends. I know their faces and they mine ... At what word, dropped in a talk I have forgotten, by what small unconscious action, they will no longer suffer me. Their faces will close and I will have become an enemy" (My Shadow 126). If these faces from the Nationalist side seemed kindly disposed, other faces were not. These faces "are different. There is no friendliness in the faces. There is no cheering, no singing, no shouting . . . The faces of these men are locked against us. They are graven faces. They are faces carved of hard substance, not of flesh, which is soft stuff. They carry their faces with pride. And they look poor, desperately poor" (76). These were the Republicans living in the Nationalist zone. They saw her as the enemy, while the enemy saw her as friend. Her own position was clouded, for they after all were now her friends. Only they weren't, as Davis eventually found the masquerade unbearable, when a Nationalist officer began to talk about how the masses "cannot be taught . . . they are like dogs and will mind only the whip" (136). She wrote, "He fills me with fear. He is talking about me, and doesn't know it. Or does he? Am I not of the masses? Is not my heritage the labor struggle, with mother a striker, my father an organizer . . .?" $(137) .^{28}$

\footnotetext{
${ }^{28}$ In A Fearful Innocence, this episode occurs in chapter 11, titled "The Face of the Enemy."
} 
While Davis's position does become clear, the equivocal location she appears to occupy physically and politically is symbolic of a larger question: how do we locate war ideologically? Davis's displaced identity can only be taken as mere disguise if we reduce the Spanish conflict to a struggle between fascism and democracy, or some other similar cliché of this remarkably complex civil war. As she observed, "In the early days of the war, none of us could know with any certainty whether a given village or surrounding region had gone over to the insurgents or had remained loyal to the Republic" (Fearful Innocence 138). She herself was carried away for a moment when young Nationalist soldiers cried out "Long Live Spain!," to which de Jouvenel and Davis replied "Long Live Spain!" "This exchange with strangers," she wrote, "moved and excited de Jouvenel and me. We were caught up in a surge of brotherhood" (139), though right after she stepped back from the gesture. Curiously, in 1940, Davis mentioned only de Jouvenel in this scene, and the phrase, "surge of brotherhood," did not appear. The later memory of the episode recuperated a deeper awareness of herself as a participant caught between identities and, perhaps more disquieting for Davis, stirred, if only briefly, by the revelation that brotherhood could be found on the other side as well.

Davis's uncertain place in her narrative, her "precarious balance," means she can never quite absorb her experience, never quite digest it, recalling the difficulties Gellhorn and Herbst had in explaining what this war was really like. During an attack, she actually lost her balance, nearly coming into contact with a dead body: "If I had touched that thing it would have burst. Oh, God, how close I came to touching - ", she wrote. "He has been burnt and his black skin is stretched tight across his putrified fat and muscle and insides. His arms reach up. His arms stretch up to embrace my fall, skidding down the rock ... [I]f I barely grazed that leather flesh, it would break and crumble and the gas of the putrid insides would rise and engulf me" (My Shadow 144). ${ }^{29}$ The horror of this dead body resides less in its appearance and more in its capacity to devour Davis's person. Her fear of touching the body speaks to that horror, but also to the inability to articulate fully the experience of war and, more broadly, the feelings the war has produced. The decomposing formlessness of "that thing" is the war, a dissolving structure but still, a structure of sorts encompassing much, I suspect, that Davis is unable to fathom or to imagine, that politics and ideology cannot explain. The moment recalls with vivid irony what Joseph North wrote: "To the writer of reportage, the fact he is describing is no corpse, it is alive, it has a place on earth."

\footnotetext{
${ }^{29}$ Few correspondents covering the Nationalist side saw very much of actual war, observed John Whitaker, one of Davis's colleagues to whom she was particularly close in Spain. "Most of them," he said, "went to the front on escorted tours, or organized by Franco's propaganda bureau, to arrive well after a battle. They saw nothing" (105).
}

This corpse is also without a face. "He grins. He grins from ear to ear," she says (144). He joins the charred face that Gellhorn cannot look at and the unseen face that Herbst can only sense in the dark. The de-facement of war creates a structure of feeling that cannot be entirely grasped because it is displaced, like civilians without homes and soldiers without faces. Gellhorn thought memory and imagination were the great deterrents. But memory and imagination can only summon forth, house the emergent form, and ask, like Augustine, "May it not be we that you want?"

\section{Further Reading}

Allen, J. Preface. In Capa [no pag.].

Anon. 2005. Study Shows Faces Are Processed Like Words. Science Daily (15 Mar). https://www.sciencedaily.com/releases/2005/03/ 050310180826.htm

Aristotle. 2007. De Anima. Trans. and ed. R.D. Hicks. Cambridge: Cambridge UP.

Augustine, St. 2006. Confessions. $2^{\text {nd }}$ ed. Trans. F.J. Sheed. Introd. Peter Brown. Ed. Michael P. Foley. Indianapolis: Hackett

Berman, M. 1988. All That Is Solid Melts Into Air: The Experience of Modernity. 1982; New York: Penguin.

Burns, J. n.d. The Noble Savage. The Penniless Press On-Line. http:// www.pennilesspress.co.uk/prose/noble savage.htm

Butler, J. 2004. Precarious Life: The Powers of Mourning and Violence. London: Verso.

Capa, R. 1938. Death in the Making. Photographs by Robert Capa and Gerda Taro. Preface Jay Allen. New York: Covici Friede.

Coleman, A.1982. Hemingway's The Spanish Earth. The Hemingway Review, 2(1), 64-67.

Dalí, S. [1942] 1993. The Secret Life of Salvador Dali. Trans. Haakon M. Chevalier. New York: Dover Publications.

Davis, F. 1981. A Fearful Innocence. Kent, OH: Kent State UP.

Davis, F. 1940. My Shadow in the Sun. New York: Carrick \& Evans.

Davison, R. A. 1988. The Publication of Hemingway's The Spanish Earth: An Untold Story. The Hemingway Review, 7(2), 122-30.

De Bueriis, M. R. 1998. Josie's Trenches: The Life and Times of Josephine Herbst. In B. Pisapia, U. Rubeo, and A. Scacchi (Eds.), Red Badges of Courage: Wars and Conflicts in American Culture (pp. 283-93). Rome: Bulzoni.

De Man, P. 1979. Autobiography as De-facement. Modern Language Notes, 94(5), 919-930.

Dell'Orto, G. 2004. 'Memory and Imagination Are the Great Deterrents': Martha Gellhorn at War as Correspondent and Literary Author. The Journal of American Culture, 27(3), 303-314.

Gellhorn, M. 1959a. The Besieged City. In The Face of War (pp. 14-25). New York: Simon and Shuster.

Gellhorn, M. 1938a. City at War. Collier's (2 Apr), 18-19, 59-60.

Gellhorn, M. 1959b. The Face of War. New York: Simon and Schuster.

Gellhorn, M. 1986. The Face of War. $3^{\text {rd }}$ rev. ed. London: Virago P.

Gellhorn, M. 1937a. Madrid to Morata. The New Yorker (24 July), 31, 34, $37-39$.

Gellhorn, M. 1996. Memory. The London Review of Books 18.24 (12 Dec.), 3.

Gellhorn, M. 1938b. Men Without Medals. Collier's (15 Jan.), 9-10, 49.

Gellhorn, M. 1937b. Only the Shells Whine. Collier's (17 July), 12-13, 64-65.

Gellhorn, M. 1941. A Sense of Direction. The Heart of Another (pp. 138 70). New York: Charles Scribner's Sons.

Gellhorn, M. 1959c. The Third Winter. In The Face of War 26-41. 
Gellhorn, M. 1952. The Undefeated. [1945]. In A. Bessie (Ed.), The Heart of Spain (pp. 435-41). New York: Veterans of the Abraham Lincoln Brigade.

Gellhorn, M. 1937c. Zoo in Madrid. Harper's Bazaar 70.2697 (July), 47, 95. Rptd. in The Heart of Another 123-28.

Hartmann, L. A. 2008. Say That We Saw Spain Die: British and American Women Writers and the Spanish Civil War. M.A. Thesis, Virginia Polytechnic Institute and State University.

Hemingway, E. [1940] 1995. For Whom the Bell Tolls. New York: Scribners.

Herbst, J. n.d. Journal Spain, unpublished diary, Josephine Herbst Papers, YCAL MSS474, Box 62, Beinecke Library, Yale University.

Herbst, J. 1937a. No Sanctuary. The Nation (2 Oct.), 354-55.

Herbst, J. 1937b. Spanish Village. The Nation (14 Aug.), 169-70.

Herbst, J. 1992. The Starched Blue Sky of Spain and Other Memoirs. Introd. Diane Johnson. 1991; New York: HarperCollins.

Herbst, J. 1937c. Three Books from Spain's Trenches. New Masses, 25(30 Nov.), 20.

Hochschild, A. 2016. Spain in our Hearts: Americans in the Spanish Civil War, 1936-1939. Boston: Houghton Mifflin Harcourt.

Hubler, A. E. 1997. Josephine Herbst's The Starched Blue Sky of Spain and Other Memoirs: Literary History 'In the Wide Margin of the Century'. Papers on Language \& Literature, 33(1), 71-98.

Johnson, D. 1997. Introduction. In Herbst, The Starched Blue Sky vii-xxv.

Keene, J. 2001. Fighting for Franco: International Volunteers in Nationalist Spain During the Spanish Civil War, 1936-39. Foreword Gabriel Jackson. London: Leicester UP.

Knightley, P. [1975] 2004. The First Casualty. The War Correspondent as Hero and Myth-Maker from the Crimea to Iraq. Baltimore: The Johns Hopkins UP.

Koch, S. 2005. The Breaking Point. Hemingway, Dos Passos, and the Murder of José Robles. New York: Counterpoint.

Langer, E. [1983] 1994. Josephine Herbst. Boston: Northeastern UP.

Levinas, E. 1996. Peace and Proximity. In A. T. Peperzak, S. Critchley, and R. Bernasconi (Eds.), Basic Philosophical Writings (pp. 16169). Bloomington: Indiana UP.

Machado, A. 1999. ¡Madrid! In F. Caudet (Ed.), Antología comentada. II. Prosa (pp. 287-291). Madrid: Ediciones de la Torre.

Marsh, W. W. 1938. One Moment, Please! Cleveland Plain Dealer (24 July).

Martínez de Pisón, I. 2005. Enterrar a los muertos. Barcelona: Seix Barral.

McLoughlin, K. 2007. Martha Gellhorn: The War Writer in the Field and in the Text. Manchester: Manchester UP.

Moorehead, C. 2003. Martha Gellhorn: A Life. London: Chatto \& Windus.

Orwell, G. [1938] 1966. Homage to Catalonia. Introd. Lionel Trilling. Boston: Beacon Press.
Paz, O. 1978. El laberinto de la soledad. Mexico City: Fondo de Cultura Económica.

Preston, P. 2009. We Saw Spain Die: Foreign Correspondents in the Spanish Civil War. New York: Skyhorse Publishing.

Roberts, N. R. 1992. Herbst and Hemingway in Spain. North Dakota Quarterly, 60(2), 204-216.

Rollyson, C. 1990. Nothing Ever Happens to the Brave: The Story of Martha Gellhorn. New York: St. Martin's Press.

Sánchez, B. A. 1980. Antonio. Ensayos y recuerdos. Barcelona: Laia.

Santiáñez, N. 2009. Goya/Clausewitz: Paradigmas de la guerra absoluta. Barcelona: Ediciones Alpha Decay.

Santiáñez, N. 2016. Showing What Cannot Be Said: Total War and the International Project of Modernist War Writing. The Massachusetts Review 57.2 (Summer) and 57.3 (Fall), 300-15, 450-62.

Schlesinger, A. Jr. 1981. Foreword. In Davis, A Fearful Innocence ix-xii.

Sommerville, C. J. 1999. How the News Makes Us Dumb: The Death of Wisdom in an Information Society. Downers Grove, IL: InterVarsity Press.

Sorel, N. C. 1999. The Women Who Wrote the War. New York: Perennial

Suárez-Galbán, E. 2011. Two Women at War: Lillian Hellman and Josephine Herbst. In The Last Good Land: Spain in American Literature (pp. 225-42). Amsterdam: Rodopi.

Usandizaga, A. 2007. Escritoras al frente: Intelectuales extranjeras en la Guerra Civil. Donostia-San Sebastián: Nerea.

Vaill, A. 2014. Hotel Florida: Truth, Love, and Death in the Spanish Civil War. New York: Farrar, Straus and Giroux.

Valis, N. 2000. Nostalgia and Exile. Journal of Spanish Cultural Studies, 1(2), 117-133.

Whitaker, J. T. 1942. Prelude to World War. A Witness from Spain. Foreign Affairs, 21(1), 103-119.

Williams, R. 1977. Marxism and Literature. Oxford: Oxford UP.

Wolff, M. 1994. Hemingway's 'On the American Dead in Spain'. In C. Nelson (Ed.), Remembering Spain. Hemingway's Civil War Eulogy and the Veterans of the Abraham Lincoln Brigade (pp. 7-17). Urbana and Chicago: $U$ of Illinois Press.

Wood, J. 1938. Introduction. In E. Hemingway, The Spanish Earth (pp. 9-15). Cleveland: The J.B. Savage Company.

Woolf, V. [1938] 1966. Three Guineas. San Diego: Harcourt Brace and Co.

Noël Valis is Professor of Spanish at Yale University. She is the author of The Culture of Cursileria: Bad Taste, Kitsch, and Class in Modern Spain, Sacred Realism: Religion and the Imagination in Modern Spanish Narrative, and the novella, The Labor of Longing, as well as the editor of Teaching Representations of the Spanish Civil War. She is a Senior Fellow of the Elm Institute. 